\title{
Attitudes toward the Use of Project-Based Learning: A Case Study of Vietnamese High School Students
}

\author{
Thao Quoc Tran', Tu Ngoc Phan Tran ${ }^{2}$ \\ ${ }^{1}$ Ho Chi Minh City University of Technology (HUTECH) \\ ${ }^{2}$ Bui Thi Xuan High School
}

\begin{abstract}
Correspondence concerning this article should be addressed to Thao Quoc Tran, Ho Chi Minh City University of Technology (HUTECH), 475A Dien Bien Phu Street, Ward 25, Binh Thanh District, Ho Chi Minh City, Vietnam. E-mail: tq.thao@hutech.edu.vn
\end{abstract}

\begin{abstract}
It is universally acknowledged that project-based learning (PBL) plays a fundamental role in language teaching and the learning process. In some developed countries with advanced education, PBL has been applied to language teaching and learning widely and effectively. However, in the context of Vietnam, PBL is unlikely to be viewed as an integral approach to enhance students' self-directed abilities in their learning. This paper aimed at investigating EFL high school students' attitudes towards PBL when they implemented PBL with the new English textbooks at Bui Thi Xuan High School in Vietnam. This study involved one hundred and fiftyfive EFL high school students in answering the questionnaire and forty students in responding to semi-structured interview questions. The quantitative data were processed by SPSS in terms of descriptive statistics (means, standard deviation, and frequency), and content analysis was used for analyzing the qualitative data. The findings of the study showed that EFL high school students expressed positive attitudes (i.e. cognition, affection, and behavior) toward PBL. The data from the semi-structured interview were coded and analyzed to make the results of the study clearer. These preliminary findings are hoped to contribute to a better understanding of the current perspectives of applying PBL into language learning in the Vietnamese context so that practical implications should be made in order to enhance the quality of teaching in English language education in Da Lat specifically and Vietnam in general.
\end{abstract}

Keywords: attitudes, high school students, PBL, Vietnamese EFL context

\section{Introduction}

\section{Background}

It is undeniable that project-based learning (PBL) is believed to be one of the ideal choices to teach students in modern classrooms. Bender (2012) indicated that when teachers utilize PBL, they change their traditional roles into the new modes of teaching. According to Dewey (1959), who is one of the pioneers of PBL, when students implement meaningful tasks related to problems in real-world situations, they can achieve more profound comprehension. Several researchers (e.g. Demir, 2020; Helle, Tynjala, \& Olkinuora, 2006; Krajcik, Czerniak \& Berger, 1999; Revelle et al., 2020) have regarded PBL as an alternative method for teaching because it is a powerful tool for encouraging students to engage more in solving real-world problems. As a matter of fact, PBL allows students to take part in learning activities as active and confident participants (Krajcik et al., 1994).

In terms of learners' attitudes, several studies have been conducted recently to achieve in-depth insights into this topic. Brown (2001) highlights the significance of attitudes on learners' learning processes. Similarly, attitudes are of importance to master a language and facilitate language acquisition (Gardner \& Lambert, 1972). Attitudes, along with cooperation in teamwork, self-concept, and $21^{\text {st }}$ century skills are the key factors that help project-based learners reinforce their learning ability, attain insightful comprehension on conceptual knowledge, and promote their learner autonomy. Obviously, learning performance can be enhanced and facilitated when students have positive attitudes. However, students' performances and results in language acquisition may deteriorate if the students have negative attitudes (Tella, Indoshi, \& Othuon, 2010). This 
means that when learners have positive attitudes toward projects associated with their own lives, they tend to acquire knowledge to solve the problems in real life more efficiently.

At the tertiary level in Vietnam, there has been more research and teaching practice on PBL and students are more likely to be accustomed to this approach; however, at the high school level, EFL students are rarely given the chance to learn through PBL, and less research on PBL has been conducted on high school students. Comprehending the imperative roles of PBL to facilitate students' learning and create productive classroom environments for the students, the MOET attempted to introduce and apply PBL in the new ten-year English textbooks designed for the National Foreign Language 2020 Project. Projects are included in each unit to help promote learner autonomy for EFL high school students and life-long learning. At Bui Thi Xuan High School, students are more familiar with carrying out projects since they started learning English with the new textbooks in 2013. In order to have a profound understanding of the students' attitudes toward project-based learning, this study aimed at identifying the attitudes toward the use of PBL among high school students in grades 10,11, and 12 at Bui Thi Xuan High School in Lam Dong Province, Vietnam. The research question was formulated for this study as follows:

- What are EFL students' attitudes toward the use of project-based learning in English language learning at Bui Thi Xuan High School?

\section{Literature Review}

\section{Project-Based Learning}

In terms of a pedagogical framework, PBL is regarded as an innovative approach in education. Bransfort, Brown, and Cocking (1999) define PBL as a powerful approach that encourages students to expand the knowledge they have learnt in a new context. Supplying another definition of PBL, Savery (2006) considers PBL to be a constructivist instructional method in which students are encouraged to work in groups or interact with each other to apply the knowledge in the classroom in order to solve problems in their real lives under the teacher's instruction. In short, PBL is a learner-centered approach that triggers students' collaboration and critical thinking skills through experience solving real-life problems.

\section{Self-regulated language learning enhancement}

As the major purpose of PBL is to assist students by enhancing their self-regulated language learning (SRLL), students primarily learn how to learn on their own when implementing PBL (Vaiz, 2003). As engaging in implementing PBL through the process of collecting information from different material sources as well as attaining knowledge via analysis and synthesis, students stand a greater chance of comprehending their lessons more thoroughly and applying them into their real-life situations. Through project implementation, their selfregulation in learning improves day by day (e.g., Hoang, 2009; Nguyen, 2017; Tran \& Tran, 2019; Yilmaz, Yilmaz \& Keser, 2020).

\section{$21^{\text {st }}$ century skills improvement}

PBL offers substantial benefits to learners as it encourages active inquiry and higher-order thinking skills (Thomas, 1998). Moreover, PBL helps them constitute improvement in self-reliance, attendance, and attitudes toward learning and then has a great influence on students' learning behaviors and even their performance (Thomas, 2000, Tran \& Duong, 2013; Tran \& Nguyen, 2020). Additionally, thanks to PBL, learners develop their $21^{\text {st }}$ century skills including collaborative skills, creative skills, critical thinking skills, problem-solving skills, decision-making skills, communicative skills, etc., all of which are absolutely effective for their own lives and help improve their sense of responsibility (Dori \& Tal, 2000; Nguyen, 2011; Pham, 2014; Tran \& Tran, 2019).

\section{Speaking competence development}

PBL helps students enhance their speaking competence as it provides them with room for enriching their vocabulary (Torres \& Rodríguez, 2017). Accordingly, students can express their own ideas, communicate appropriate messages and complete tasks in projects. These authors highlight that when students have a wide range of vocabulary, they can overcome their fear of speaking and become more confident. Likewise, it is PBL that enhances students' speaking skills in the classroom, i.e. students become more and more confident when 
talking in front of the class (Pham, 2014). As a result, students are in favor of addressing their own experiences and cultures in the target language (Truong, 2017).

\section{Opportunities for Self-Assessment}

Railsback (2002) claims that PBL may engage culturally diverse learners as a wide range of learning opportunities are offered to students in the classroom. Furthermore, students can assess their learning process and their production on their own and provide constructive feedback to each other (Gubacs, 2004). When students assess themselves, they may take control of their studies and manage their learning more independently. This is meaningful to students as they can enhance their strengths or eradicate their weaknesses (Tran \& Tran, 2019).

\section{More Active Learning Engagement}

It is universally believed that PBL triggers students' engagement in their learning (Cornell \& Clarke, 1999). These authors also affirm that not only does PBL supply students with team collaboration and new skills while implementing hands-on activities but it also allows weak students to make progress at their own pace. Research on collaborative learning shows that when working in groups positively, students have a tendency to obtain higher learning outcomes than those who work in traditional classroom environments (Gillies \& Ashman, 2000). This is because low achievers can receive explanations, aid, and support from their better partners, which helps them clarify the issues and build comprehension easily. Furthermore, planning, revising, and reflecting to complete projects may help students achieve expected outcomes in their learning (Nguyen, 2011).

\section{Learner Attitudes}

Many recent researchers have concentrate on conducting research on learner attitudes so as to achieve indepth insights into this topic and investigate how attitudes affect learning acquisition. According to Rokeach (1969, as cited in Smith, 1971), "an attitude is a relatively enduring organization of beliefs around an object or a situation, predisposing one to respond in some preferential manner" (p. 52). Gardner and Lambert's (1972) definition is that "an individual's attitude is an evaluative reaction to some referent or attitude object on the basis of the individual's beliefs or opinions about the referent" (p. 36).

There are three components of attitudes, namely affective, cognitive, and behavioral factors. First, the affective component is seen as the emotional response towards an attitude object; therefore, there have been a number of studies on this issue. Eagly and Chaiken (1998) define the affective factor as the "feelings, moods, emotions, and sympathetic nervous system activity that people have experienced in relation to an attitude object and subsequently associate with it" (p. 272). These authors claim that the affective component is based mainly on emotional experiences and preferences. It reflects the likes or dislikes of a person towards an object. The affective factor should not be judged in terms of only the beliefs because emotion works simultaneously with the cognitive factor. Regarding PBL, when students have positive or negative attitudes towards PBL, they can have a great effect on their learning strategies (Railsback, 2002).

Second, the cognitive component of attitudes is beliefs, thoughts, and attributes that individuals express about an object. It is the general knowledge that a person possesses. It is based on how people think about the attitude objects. Schiffman and Kanuk (2004) state that the cognitive factor consists of information and perceptions. These two elements can be found through the mixture of experiences with attitude objects and information from different sources. The cognitive component reflects the ways people think about objects and their attributes towards the objects. In terms of PBL, it is believed that when people associate an object with positive attributes, they have more positive attitudes toward it.

Third, the behavioral component consists of a person's response towards attitude objects. According to Defleur and Westie (1963), it involves a person's response or reaction to doing something related to an attitude object. The behavioral component is in attempt to explain the participation of an individual in tasks as well as actions concerning an attitude object. It has a great influence on the ways individuals act or behave.

To sum up, the affective component is based on the emotions and feelings about attitudinal objects, whereas the cognitive component is related to perceptions, conceptions, and beliefs, and the behavioral component focuses more on the expressions of behavioral intention or action. 


\section{Previous studies}

In order to explore and apply the new educational approaches or methods in the teaching and learning process, many researchers have recently concentrated more on PBL as an effective way to help students become more active in learning. Many studies by different researchers such as Baran and Maskan (2010), Kaldi, Filippatou, and Govaris (2011), and Van Rooij (2009) explored how PBL had great impacts on students' attitudes and their academic achievement. Moreover, the results showed that the use of PBL increases students' success in their learning process.

In terms of the students' attitudes towards PBL, only a few studies have recently been conducted. Han (2017) conducted a study in six secondary schools Korea with 840 students in order to investigate the students' attitudes towards science, technology, engineering, and mathematics (STEM) PBL and discovered the relationships between their attitudes and the interests in pursuing a STEM major. With the employment of a questionnaire using a 5-point Likert type scale, the results of the study showed that the students who had positive attitudes towards PBL were in favour of choosing STEM major in the future. In another study by Haryatti (2017), the researchers aimed to determine the students' attitudes towards the use of PBL in the application of Computer Assisted Language Learning (CALL). 40 participants were involved in this study. The results revealed that the students' attitudes towards PBL were positive. In general, most of the recent studies indicated that students expressed positive attitudes towards PBL.

In the context of Vietnam, although a great deal of research has been implemented recently on PBL, a few of them focus on the students' attitudes towards PBL. Truong (2017) conducted a study at Vien Dong College to investigate the students' attitudes towards project work for fostering student autonomy in English speaking classes. Eighty-one students were chosen and the research instruments were an open-ended questionnaire, semi-structured interviews, and class observations. The findings of the study showed that students expressed positive attitudes towards project work as well as the possibility to improve their learner autonomy. In general, most of the recent studies indicated that EFL students express positive attitudes towards PBL. Pham (2014) conducted a survey at An Lao High School to investigate the students' attitudes towards PBL and its effects on students' English speaking skill. With the employment of tests, questionnaires, and interviews, the results of the study revealed that students showed positive attitudes towards PBL and it helped students improve their speaking performance. However, little research on EFL high school students has been done recently to identify their attitudes towards PBL.

\section{Methodology}

\section{Research Site}

The study was conducted in Bui Thi Xuan High School, which was chosen as one of three high schools in Lam Dong Province to implement the new English textbooks designed by the Ministry of Education and Training in Vietnam in 2013. In the new textbooks, one of the new sections introduced was projects, which encourage students to take the first step towards getting familiar with PBL.

\section{Research Participants}

The participants of the study were 155 EFL students from five classes of grades 10, 11, and 12 at Bui Thi Xuan High School, all of whom were using the new English textbooks of the Ministry of Education and Training in Vietnam. There were 155 copies of the questionnaire delivered to the high school students; however, 147 copies were returned and collected by the researchers. As for the gender aspect, the number of male students was 68 while that of female students was 79 , which accounted for $46.3 \%$ and $53.7 \%$, respectively. The age of the participants was divided into three main categories, including 15 years old, 16 years old, and over 16 years old with a frequency of 54,59, and 34 respectively. The age of the participants across the three grades: 10,11 , and 12 was $36.73 \%, 40.14 \%$, and $23.13 \%$, respectively. 
Table 3.1

Participants' general information

\begin{tabular}{lllcc}
\hline \multirow{2}{*}{ No. } & \multirow{2}{*}{ Information } & \multicolumn{3}{c}{$\mathbf{N = 1 4 7}$} \\
\cline { 3 - 5 } 1 & \multirow{2}{*}{ Gender } & Male & $\mathbf{F}$ & $\mathbf{\%}$ \\
\hline \multirow{3}{*}{2} & Female & 68 & 46.3 \\
& \multirow{2}{*}{ Age } & 15 years old & 54 & 53.7 \\
\hline & & 16 years old & 59 & 40.73 \\
& & Over 16 years old & 34 & 23.13 \\
\hline
\end{tabular}

Note: F: Frequency; \%: Percent

\section{Research Instruments}

As the nature of the study was mixed-method, quantitative and qualitative, two instruments were utilized: a questionnaire and semi-structured interviews to collect the data. To ensure validity and reliability, the questionnaire along with the interview question were reviewed by an expert in the field of English language studies before it was delivered to the participants of the study.

\section{Questionnaire}

The questionnaire was designed with 60 questions, separated into two parts, A and B: the participants' general information and the students' attitudes towards PBL. In part A, students were required to give their demographic information, including their gender, their age, their experience learning English, as well as the time they spent implementing projects. In part B, students were asked to fill out a questionnaire, in which a Likert Scale was used to gauge the students' responses. Part B aimed to investigate the students' attitudes towards PBL and the responses included ' 5 ' for Strongly Agree (SA), '4' for Agree (A), ' 3 ' for Neutral (N), '2' for Disagree (D) and ' 1 ' for Strongly Disagree (SD). In order to collect the best results, the questionnaire was translated into Vietnamese to make it easy for the students to answer and avoid misunderstandings. Cronbach Alpha $\alpha$ was at .905, so the reliability of the questionnaire was high.

\section{Semi-Structured Interview}

The semi-structured interview was chosen to prepare questions on each strategy in advance in order to cover the target aspects of the interview. The questions for interview were translated into Vietnamese language and the students also answered in Vietnamese. There was a pilot interview to see whether the questions obtained intended information.

\section{Data Collection Procedure}

The data collection was conducted from the end of April through the beginning of May in the academic school year 2018-2019. The questionnaire was delivered to students who learnt English with the new English textbooks. Before filling out the questionnaire, students were asked if anything needed to be explained. Each student spent at least fifteen minutes completing the questionnaire.

The interview was conducted with ten groups of students who were chosen randomly from five classes learning with the new English textbooks. The purpose of the interview was explained in advance. Each student spent five to seven minutes responding to the interview questions. The students' answers were recorded for content analysis. In regards to the semi-structured interview, ten groups of four students were invited for the interview. The interviews were conducted in Vietnamese and recorded for later analysis.

\section{Data Analysis Procedure}

This mixed methods design generated both qualitative and quantitative data. The quantitative data from the questionnaires were analyzed using SPSS 21.0 in terms of (mean, standard deviation, and frequency), and the meaning of the mean scores for the students' attitudes towards PBL were interpreted as follows: 
- 1-1.80: strongly disagree

- 1.81-2.60: disagree

- 2.61-3.40: neutral

- 3.41- 4.20: agree

- 4.21 - 5.00: strongly agree

Qualitative data were collected and analyzed from semi-structured interview questions. Data were recorded and translated into English for research purposes only. After that, the data were analyzed by the logical analysis approach.

The responses from the interview were analyzed by using the content analysis approach, which means that three steps, viz. familiarizing and organizing, coding and recoding, and summarizing and interpreting were employed. The five groups' interviewees were coded from S1 to S40.

\section{Results and Discussion}

\section{Results}

As shown in Table 1, it is noted that the total mean scores of students' attitudes towards PBL was rather high $(\mathrm{M}=3.83 ; \mathrm{SD}=.42)$. This means that high school students' attitudes towards the PBL were relatively positive.

\section{Table 1}

Total mean scores of attitudes towards PBL

\begin{tabular}{llcc}
\hline \multirow{2}{*}{ No. } & \multirow{2}{*}{ Students' attitudes towards PBL } & \multicolumn{2}{c}{$\mathbf{N = 1 4 7}$} \\
\cline { 3 - 4 } & & $\mathbf{M}$ & SD \\
\hline $1 \quad$ Students' attitudes towards PBL & 3.83 & .42 \\
\hline \multicolumn{3}{c}{ Note: M: mean; SD: Standard deviation }
\end{tabular}

The results in Table 2 revealed that students expressed positive attitudes towards PBL in three components of attitudes $(\mathrm{M}=3.83 ; \mathrm{SD}=.42)$. Furthermore, the students' attitudes for each separated component consisting of cognitive attitudes, affective attitudes, and behavioral attitudes were relatively high. Despite having the high mean scores, the students' responses to each component were not the same. It is evident that the students' responses to affective attitudes ( $M=3.99 ; \mathrm{SD}=.55)$ were the highest components of the three attitude components, followed by the students' responses to cognitive attitudes $(\mathrm{M}=3.86 ; \mathrm{SD}=.43)$. Compared with the two components mentioned above, those of behavioral attitudes ranked third ( $\mathrm{M}=3.59 ; \mathrm{SD}=.64)$.

\section{Table 2}

EFL high school students' attitudes towards PBL

\begin{tabular}{|c|c|c|c|}
\hline \multirow{2}{*}{ No. } & \multirow{2}{*}{ Attitudes } & \multicolumn{2}{|c|}{$\mathrm{N}=147$} \\
\hline & & M & SD \\
\hline 1 & Cognitive attitudes & 3.86 & .43 \\
\hline 2 & Affective attitudes & 3.99 & .55 \\
\hline 3 & Behavioral attitudes & 3.59 & .64 \\
\hline Total & & 3.83 & .42 \\
\hline
\end{tabular}

Note: M: Mean; SD: Standard deviation

\section{Cognitive Attitudes}

In terms of the high school students' cognition-related attitudes towards PBL, as shown in Table 3, it is evident that EFL high school students expressed positive attitudes towards PBL $(M=3.86 ; \mathrm{SD}=.432)$. The results of the study revealed that most EFL high school students agreed that PBL enhanced their speaking competence $(\mathrm{M}=4.16 ; \mathrm{SD}=.794)$ and communicative skills when implementing PBL in the new English textbooks $(M=4.03 ; \mathrm{SD}=.939)$. Students found the importance of doing the projects in the English textbooks $(\mathrm{M}=3.79 ; \mathrm{SD}=.796)$ and expanding their knowledge by doing the projects in the English textbooks $(\mathrm{M}=3.96$; 
$\mathrm{SD}=.906)$. With regard to self-regulated learning, the students also agreed that PBL helped them to enhance their self-regulated learning performance $(\mathrm{M}=3.95 ; \mathrm{SD}=847)$. In terms of the students' attitudes towards the $21^{\text {st }}$-century skills, students recognized the improvement in their creative skills $(\mathrm{M}=3.88 ; \mathrm{SD}=.784)$, decisionmaking skills ( $\mathrm{M}=3.80$; $\mathrm{SD}=.852)$, critical thinking skills $(\mathrm{M}=3.90 ; \mathrm{SD}=.830)$, problem-solving skills $(\mathrm{M}=3.84$; $\mathrm{SD}=.860)$, and communicative skills $(\mathrm{M}=4.03 ; \mathrm{SD}=.939)$. Concerning learning assessment, the EFL high school students expressed agreement in their improvement of the ability to assess their own learning process $(\mathrm{M}=3.57 ; \mathrm{SD}=.929)$ as well as assess their classmates' production on their own $(\mathrm{M}=3.70 ; \mathrm{SD}=.895)$. Students also agreed that their learning outcomes improved after doing the projects in the textbooks $(\mathrm{M}=3.76$; $\mathrm{SD}=.855)$.

Table 3

EFL high school students' cognitive attitudes towards PBL

\begin{tabular}{|c|c|c|c|}
\hline \multirow{2}{*}{ No. } & \multirow{2}{*}{ Cognitive Attitudes } & \multicolumn{2}{|c|}{$\mathrm{N}=\mathbf{1 4 7}$} \\
\hline & & M & SD \\
\hline 1.1 & PBL helps me to enhance my self-regulated learning performance. & 3.95 & .847 \\
\hline 1.2 & I improve my creative skills when doing the projects in the textbooks. & 3.88 & .784 \\
\hline 1.3 & I improve my decision-making skills when doing the projects in the textbooks. & 3.80 & .852 \\
\hline 1.4 & I improve my critical thinking skills when doing the projects in the textbooks. & 3.90 & .830 \\
\hline 1.5 & I improve my problem-solving skills when doing the projects in the textbooks. & 3.84 & .860 \\
\hline 1.6 & I improve my communicative skills when doing the projects in the textbooks. & 4.03 & .939 \\
\hline 1.7 & PBL helps me to enhance my speaking competence. & 4.16 & .794 \\
\hline 1.8 & I improve my ability to assess my own learning process. & 3.57 & .929 \\
\hline 1.9 & I improve my ability to assess the production of my friends on my own. & 3.70 & .895 \\
\hline 1.10 & It is important for me to do the projects in the English textbooks I am using. & 3.79 & .796 \\
\hline 1.11 & It is important for me to expand my knowledge in the textbooks by doing the projects in the English textbooks. & 3.96 & .906 \\
\hline 1.12 & My learning outcomes improve after doing the projects in the textbooks. & 3.76 & .855 \\
\hline Total & & 3.86 & .432 \\
\hline
\end{tabular}

Note: M: mean; SD: Standard deviation

Qualitatively, it was shown that all of the students who answered the interview questions agreed that PBL played an important role in their English language learning. They explained:

"PBL is important because it improves skills for EFL high school students for their future career." (S2)

"PBL is a must as it forms the ability of using different soft skills for students." (S11)

"It is important to do PBL as students to improve our skills and self-regulated learning." (S22)

Moreover, it was noticeable that PBL helped students improve their studies in various ways, some of which were listed as follows: skill improvements such as time management skill, technology skill, presentation skill, problem-solving skill, creative skill, critical thinking skill and self-assessment skill, SRLL performance, teamwork engagement, knowledge expansion, and others. For example, S10 reported, "When doing PBL, I improve my time management skills and know how to do a project before the deadline." Meanwhile, S2 admitted the improvement in SRLL thanks to PBL implementation.

With regard to $21^{\text {st }}$ century skills, the EFL high school students expressed more agreement on improvements in the use of $21^{\text {st }}$ century skills when they implemented PBL. It was obvious that collaborative skill and technological skill were the two skills that the EFL high school students improved the most when they implemented PBL. Additionally, communication skill, self-regulated learning skill, creative skill, critical thinking skill, problem-solving skill, decision-making skill, time management skill, and self-evaluation skill were believed to be indispensable in the globalized world.

In conclusion, it can be noted that PBL helps high school students improve their self-regulated language learning, their speaking competence as well as their $21^{\text {st }}$ century skills including creative skills, decision- 
making skills, critical thinking skills, problem-solving skills, and communicative skills. Their opportunities to self-assess their own projects as well as those of their friends also improved. More importantly, the EFL high school students recognized the importance of implementing PBL in the English textbooks as well as broadening their knowledge from the textbooks. As a result, they achieved the expected outcomes in their learning of English.

\section{Affective Attitudes}

Students' affective attitudes towards PBL were evaluated by six measured items. As shown in Table 4, the EFL high school students showed positive attitudes towards implementing different activities in PBL (M=3.99; $\mathrm{SD}=.558$ ). Most of the EFL high school students agreed that they became more responsible to work in teams while implementing hands-on activities ( $\mathrm{M}=4.14, \mathrm{SD}=.799)$, found it helpful to work together to solve the problems with their friends $(\mathrm{M}=4.12$; $\mathrm{SD}=.835)$, felt more confident searching for information through different sources on their own $(\mathrm{M}=4.03 ; \mathrm{SD}=.860)$, and felt more confident expressing their own ideas in front of the class $(\mathrm{M}=3.80 ; \mathrm{SD}=.899)$. As a result, they found it enjoyable to cooperate with their classmates to do the projects in the textbooks $(\mathrm{M}=3.87 ; \mathrm{SD}=.974)$ as well as interesting to engage more in the classroom activities $(\mathrm{M}=4.00 ; \mathrm{SD}=.868)$.

\section{Table 4}

EFL high school students' affective attitudes towards PBL

\begin{tabular}{|c|c|c|c|}
\hline \multirow{2}{*}{ No. } & \multirow{2}{*}{ Affective Attitudes } & \multicolumn{2}{|c|}{$\mathrm{N}=147$} \\
\hline & & M & SD \\
\hline 1.13 & I feel more confident searching for the information through different sources on my own. & 4.03 & .860 \\
\hline 1.14 & I find it interesting to engage more into the classroom activities. & 4.00 & .868 \\
\hline 1.15 & I find it enjoyable to cooperate with my classmates to do the projects in the textbooks. & 3.87 & .974 \\
\hline 1.16 & I feel more confident expressing my own ideas in front of the class. & 3.80 & .899 \\
\hline 1.17 & I become more responsible to work in teams while implementing hands-on activities. & 4.14 & .799 \\
\hline 1.18 & I find it helpful to work together to solve the problems with my friends. & 4.12 & .835 \\
\hline Total & & 3.99 & .558 \\
\hline
\end{tabular}

Note: M: Mean; SD: Standard deviation

Turning to the affective attitudes that help EFL high school students improve their studies when implementing PBL, from the data collected in the interview, it was evident that EFL high school students had positive affective attitudes towards PBL. Some students gave positive comments as follows:

“Thanks to implementing PBL, I become more responsible when working in groups. I try to complete my assigned tasks on time." (S33)

"I am more helpful when working in groups when I carried out the tasks in PBL. I am more eager to assist my friends if necessary." (S21)

In short, the EFL high school students thought they had more active learning engagement. When implementing PBL, they became more confident, helpful, enjoyable, and excited.

\section{Behavioral Attitudes}

The high school students' behavioral attitudes towards PBL were measured by five items. Although the means of behavioral attitudes were lower than those of cognitive and affective attitudes, their behavioral attitudes were rather positive $(\mathrm{M}=3.59 ; \mathrm{SD}=.648)$. The results shown in Table 5 revealed that many students agreed that when they implemented PBL, they had more time to practice speaking skill $(\mathrm{M}=3.80 ; \mathrm{SD}=.926)$ and selfregulated learning strategies $(\mathrm{M}=3.61 ; \mathrm{SD}=1.017)$. Furthermore, the time for self-regulated learning increased more $(\mathrm{M}=3.41 ; \mathrm{SD}=1.004)$. With regard to improvement in $21^{\text {st }}$-century skills, the participants expressed their agreement that they utilized various $21^{\text {st }}$-century skills when they did PBL in the textbooks $(\mathrm{M}=3.60 ; \mathrm{SD}=.881)$ and they concentrated more on giving constructive feedback for their friends $(\mathrm{M}=3.59$; $\mathrm{SD}=1.039)$. 
Table 5

EFL high school students' behavioral attitudes towards PBL

\begin{tabular}{llcc}
\hline \multirow{2}{*}{ No. } & & Behavioral Attitudes & N=147 \\
\cline { 3 - 4 } & & M & SD \\
\hline 1.19 & I spend more time for self-study when doing the projects in the textbooks. & 3.41 & 1.004 \\
1.20 & I use different $21^{\text {st }}$ century skills to complete my projects in the textbooks. & 3.60 & .881 \\
1.21 & I spend more time practicing speaking skill when doing the projects in the English textbooks. & 3.80 & .926 \\
1.22 & I pay attention to providing constructive feedback to my friends. & 3.59 & 1.039 \\
1.23 & I spend more time for my self-regulated learning strategies when implementing projects in the textbooks. & 3.61 & 1.017 \\
\hline Total & & $\mathbf{3 . 5 9}$ & $\mathbf{. 6 4 8}$ \\
\hline
\end{tabular}

Note: M: Mean; SD: Standard deviation

Aligning with the quantitative data, the qualitative data indicated that EFL high school students also showed positive behavioral attitudes towards PBL. Most of the interviewees agreed with this:

"I become a more self-regulated learner as I spend more time on my learning to do the project. I have spent from three to five hours on self-learning at home." (S18)

"It was difficult for me to assess my friends' work and products before, but now I know how to give feedback for my friends." (S35)

In summary, the EFL high school students expressed positive behavioral attitudes towards project implementation in the English textbooks. Some positive signs were listed as more time spent for SRLL performance, on self-regulated learning strategies, and for practicing speaking skills. The students also applied a wide range of $21^{\text {st }}$ century skills during project implementation. Significantly, students concentrated on giving productive feedback to their friends.

\section{Discussion}

In this section, the study results are discussed to shed light on the issue presented in the research question. The results of this study revealed that EFL high school students expressed positive attitudes towards PBL in three attitude components, which consisted of cognitive, affective, and behavioral attitudes. This result of the current study is partially supported by the previous research carried out by Hoang (2012) and Truong (2017). It is noticeable that although several previous studies indicated the challenges that students may encounter when they undertook PBL, the EFL high school students in this study still expressed positive attitudes towards PBL.

In terms of cognitive attitudes, the participants expressed agreement that they enhanced their self-regulated language learning, their speaking competence, and their $21^{\text {st }}$-century skills by means of PBL. The findings on SRLL improvement by PBL partially had the same opinion with Hoang (2009) and Nguyen (2017), who agreed that thanks to PBL, students' self-regulation improved gradually. Some of the $21^{\text {st }}$ century skills mentioned in this study were creative skill, decision-making skill, critical thinking skill, problem-solving skill, communicative skill, technology skill, time management skill, and self-assessment skill. The findings were aligned with Dori and Tal (2000), Nguyen (2011), and Pham (2014) on the integral roles of PBL towards the enhancement of $21^{\text {st }}$ century skills in creating an effective learning environment for students. Moreover, the EFL high school students also believed that it was of importance to implement PBL in the English textbooks and enrich their knowledge from the English textbooks.

Concerning affective attitudes, the EFL high school students agreed that they engaged more in an active learning environment. PBL helped them improve their confidence, helpfulness, sense of responsibility, and interest in learning.

With respect to behavioral attitudes, the EFL high school students expressed positive responses towards project implementation in the new English textbooks. Students believed that they became more self-regulated in their 
language learning and applied more SRLL strategies as well as $21^{\text {st }}$ century skills when they conducted their projects as Nguyen (2015) stated in his research. Furthermore, their speaking skill improved a lot as they spent more time practicing speaking in front of the class. This finding in affective attitudes was confirmed by Pham (2014) and Torres and Rodríguez (2017) about speaking skill improvements through PBL. In the same line with Gubacs (2004), this study indicated that another skill that students concentrated on more was the selfassessment skill, which they applied to evaluate their own projects as well as those of their friends. They paid more attention to providing productive feedback on their partners' projects. The findings supported the principles of PBL by Barron et al (1998) and Cocco (2006).

In short, besides the positive attitudes that EFL high school students had when they implemented PBL, they recognized the significance of PBL for their SRLL as well as the improvement of various $21^{\text {st }}$ century skills.

The results of this study throw light on EFL high school students' attitudes towards PBL. With reference to cognitive, affective, and behavioral attitudes, the results of this study revealed that the students held positive attitudes towards PBL. In terms of cognitive attitudes, the students agreed that they enhanced their selfregulated language learning, their speaking competence as well as their $21^{\text {st }}$ century skills through undertaking PBL. Relating to affective attitudes, the students believed that PBL helped them engage more in an active learning environment and improve their confidence, helpfulness, sense of responsibility, and interest in learning. In terms of behavioral attitudes, the students became positive towards project implementation in the new English textbooks. In short, the EFL high school students' attitudes towards PBL were positive.

In order to overcome the challenges of implementing PBL in high schools in Vietnam, some pedagogical implications are introduced below.

\section{PBL - a Compulsory activity at High School in Vietnam.}

PBL has to be made a compulsory activity for all students at high schools in Vietnam. EFL high school students are required to implement PBL more and more because it is obvious that both teachers and students are benefiting when implementing PBL. Furthermore, it is vital that when students implement PBL, they should be assessed using oral tests or fifteen-minute tests or even forty-five-minute tests (Tran \& Tran, 2019). Hence, the employment of PBL in English language teaching and learning should be encouraged..

\section{The Positive Changes in the Roles of High School Teachers and Students}

In order to achieve their goals, it is important for students to be equipped with some essential skills and the readiness to shift into new ways to learn. When they are ready to shift into new active roles, utilize innovation pedagogy, and even change their personal beliefs, PBL can be implemented effectively and successfully (Truong, 2017). Moreover, when teachers can overcome problems such as poor school infrastructure and the lack of available resources and time, they can foster their students' creativity and enthusiasm by implementing PBL (Tran \& Tran, 2019).

\section{Students' Positive Attitudes Towards PBL}

Students' positive attitudes towards PBL are also crucial factors to trigger students' eagerness and interests. When EFL students express positive attitudes towards the projects relating to their real lives, it is possible for them to acquire knowledge and apply it to solve the problems in real life more effectively and efficiently.

\section{Adequate Training for High School Teachers and Students}

It is essential that Vietnamese high school teachers, whose new roles are instructor, facilitator, supervisor, and monitor, be supplied with appropriate training by the MOET and the DOET. Besides being equipped with adequate skills, teachers should also be supplied with the process of project implementation as well as ways to evaluate students (Nguyen, 2017). Moreover, it is critical that the teachers who implement the project be experienced instructing students on to do projects. High school students in Vietnam, at the center of the learning process, should also be well prepared with the basic knowledge and soft skills to implement PBL effectively (Tran \& Tran, 2019). 


\section{Support from stakeholders}

It is essential to engage all of the stakeholders involved in PBL implementation in high schools. Along with the efforts of teachers and students, these stakeholders play an important role encouraging teachers and students to apply PBL in their language classrooms. Tran and Tran (2019) suggest that they should update and supply information for the students and teachers through a variety of sources. The MOET and DOET in each city or province in Vietnam should organize more training courses or design a forum to provide teachers with essential information on project implementation and evaluation.

\section{Conclusion}

This study has some limitations resulting from the nature and process of research that could affect the generalizability of the findings. First of all, although the study used both quantitative and qualitative with two instruments, including a questionnaire and semi-structured interviews, it will be better if the researcher use pre-tests and post-tests in order to compare and contrast the results of the study. However, due to the time constrains, it was impossible for the researcher to carry out pre-tests and post-tests. Another limitation of this study is that it does not provide a complete picture of PBL among a large population. The number of participants, the students who studied the new English textbooks, was only at Bui Thi Xuan High School. It would be better if the participants of the study were expanded to other high schools in Lam Dong province for further studies.

\section{Conflict of Interest}

The authors declare that they have no conflict of interest.

\section{References}

Baran, M., \& Maskan, A. (2010). The effect of project-based learning on pre-service physics teachers electrostatic achievements. Cypriot Journal of Educational Sciences, 5(4), 243-257.

Barron, B., Schwartz, D., Vye, N., Moore, A., Petrosino, L., \& Bransford, J. (1998). Doing with understanding: lessons from research on problem and project-based learning. The Journal of the Learning Sciences, 7(3), 271311. https://doi.org/10.1080/10508406.1998.9672056

Bender, W. N. (2012). Project-based learning: differentiating instruction for the 21st century. Corwin Press.

Bradford, M. (2005). Motivating Students through Project-Based Service Learning. T.H.E. Journal, 32(6), 29-30.

Bransford, J. D., Brown, A. L., Cocking, R. R. (Eds.) (1999). How people learn: Brain, mind, experience and school. National Academy Press.

Brown, H. D. (2001). Principles of language learning and teaching. Foreign Language Teaching and Research Press.

Cocco, S. (2006). Student leadership development: The contribution of project-based learning [Unpublished Master's thesis]. Royal Roads University.

Cornell, N., \& Clarke, J. (1999). The cost of quality: evaluating a standards-based design project. National Association for Secondary School Principals Bulletin.

DeFleur, M. L., \& Westie, F. R. (1963). Attitude as a scientific concept. Social Forces, 42,17-31.

Demir, C. G. (2020). An overview of project-based learning practices within the context of 21st century skills. In Paradigm Shifts in 21st Century Teaching and Learning (pp. 36-52). IGI Global.

Dewey, J. (1959). Dewey on education. Teachers College Press.

Dori, Y., \& Tal, R. (2000). Formal and informal collaborate projects: Engaging in industry with environment awareness. Science Education, 84(1), 95-113.

Eagly, A., \& Chaiken, S. (1998). Attitude structure and function. Handbook of social psychology. McGrow Company. Gardner, R., \& Lambert, W. (1972). Attitudes and Motivations in Second Language Learning. Newbury House.

Gillies, R. M., \& Ashman, A.F. (2000). The effects of cooperative learning on students with learning difficulties in the lower elementary school. The Journal of Special Education, 34(1), 19-27. https://doi. 
org/10.1177/002246690003400102

Gubacs, K. (2004). Project-based learning: A student-centered approach to integrating technology into physical education teacher education. Journal of Physical Education, Recreation and Dance, 75(7), 33-37. http://dx.doi. org/10.108 0/07303084.2004.10607272

Han, S. (2017). Korean students' attitudes toward STEM project-based learning and major selection. Educational Sciences: Theory \& Practice, 17, 529-548. http://dx.doi.org/10.12738/estp.2017.2.0264

Haryatti, S. (2017). EFL Students' Perspectives of Applying CALL through Project-Based Learning. UHAMKA International Conference on ELT and CALL (UICELL) (pp. 23-24). UNPAM.

Helle, L., Tynjala, P., \& Olkinuora, E. (2006). Project-based learning in post-secondary education - theory, practice and rubber sling shots. Higher Education, 51, 287-314. http://dx.doi.org/10.1007/s10734-004-6386-5

Hoang T. N. D. (2009). Magazine as project-based learning. In S. Rilling \& M. Dantas-Whitney (Eds.), TESOL Classroom Practice Series. Authenticity in the classroom and beyond: Adult learners (pp. 37-45). TESOL, Inc

Hoang T. N. D. (2012). Making news: A successful example of project-based learning. Language Education in Asia, 2012, 3(1), 96-105. http://dx.doi.org/10.5746/LEiA/12/V3/I1/A09/Diem

Kaldi, S., Filippatou, D., \& Govaris, C. (2011). Project-based learning in primary schools: Effects on pupils' learning and attitudes. Education, 39(1), 35-47. https://doi.org/10.1080/03004270903179538

Krajcik, J. S., Blumenfeld, P. C., Marx, R. W., \& Soloway, E. (1994). A collaborative model for helping middle grade science teachers learn project-based instruction. The Elementary School Journal, 94, 483-497. https:// doi.org/10.2307/1001838

Krajcik, J. S., Czerniak, CM \& Berger, CF (1999). Teaching science: a project-based approach. McGraw-Hill College.

Nguyen T. V. L. (2011). Project-based learning in teaching English as a foreign language. VNU Journal of Science, Foreign Languages, 27, 140-146.

Nguyen V. K. (2015). Towards Improving ESP Teaching/Learning in Vietnam's Higher Education Institutions: Integrating Project-Based Learning into ESP Courses. International Journal of Languages, Literature and Linguistics, 1(4), 227-232. https://doi.org/10.18178/ijlll.2015.1.4.44

Nguyen V. L. (2017). Promoting learner autonomy: Lesson from using project work as a supplement in English skills courses. Can Tho University Journal of Science, 7, 118-125. https://doi.org/10.22144/ctu.jen.2017.057

Pham T. T. H. (2014). Developing students' speaking skill through Project-based learning [Unpublished Master's thesis]. Vietnam National University.

Revelle, K. Z., Wise, C. N., Duke, N. K., \& Halvorsen, A. L. (2020). Realizing the promise of project-based learning. The Reading Teacher, 73(6), 697-710. https://doi.org/10.1002/trtr.1874

Savery, J. R. (2006). Overview of problem-based learning: Definitions and distinctions. Interdisciplinary Journal of Problem-based Learning, 1(1), 9-20. https://doi.org/10.7771/1541-5015.1002

Schiffman, L. G., \& Kanuk, L. L. (2004). Consumer behavior (8th ed.). Prentice Hall.

Railsback, J. (2002). Project-based instruction: Creating excitement for learning. Northwest Regional Educational Laboratory.

Tella, J., Indoshi, F. C., \& Othuon, L. A. (2010). Relationship between students' perspectives on the secondary school English curriculum and their academic achievement in Kenya. Educational Research, 1, 390-395.

Thomas, J. W. (1998). Project-based learning: Overview. Buck Institute for Education.

Thomas, J. W. (2000). A review of research on project-based learning. Autodesk.

Torres, A. M. V., \& Rodríguez, L. F. G. (2017). Increasing EFL learners' oral production at a public school through project-based learning. Profile Issues in Teachers' Professional Development, 19(2), 57-71. https://doi. org/10.15446/profile.v19n2.59889

Tran P. N. T. \& Tran Q. T. (2019). The important roles of project-based learning in teaching English to high school students. Proceedings of the $7^{\text {th }}$ OPENTESOL International Conference 2019 (pp. 279-294).

Tran, Q. T. \& Duong, M. T. (2013). The attitudes towards English language learning and use of self-regulated learning strategies among college non-English majors. International Journal of Scientific and Research Publications, 3(7), 1-8.

Tran, Q. T., \& Nguyen, D. X. (2020). Non-English-majored students' attitudes toward the use of Facebookbased activities in assisting English language learning. Proceedings of the International conference: Language education for global conference: Finding authentic voices and embracing meaningful practices (pp. 238-246). Vietnam National University - Ho Chi Minh Press.

Truong, T. T. C. (2017). Exploring Vietnamese students' attitude towards project works in enhancing autonomous learning in English speaking class. The Normal Lights, 11(2), $86-108$.

Vaiz, O. (2003). Use of portfolios (student development files) in project-based learning and its reflections on the learning process [Unpublished master's thesis]. Hacettepe University. 
Van Rooij, S. W. (2009). Scaffolding project-based learning with the project management body of knowledge (PMBOK ${ }^{\circledR}$ ). Computers \& Education, 52(1), 210-219. https://doi.org/10.1016/j.compedu.2008.07.012

Yilmaz, R., Yilmaz, F. G. K., \& Keser, H. (2020). Vertical versus shared e-leadership approach in online project-based learning: a comparison of self-regulated learning skills, motivation and group collaboration processes. Journal of Computing in Higher Education, 32, 628-654. https://doi.org/10.1007/s12528-020-092502 